\title{
HEALTH AND HEALTH CARE IN NORTHERN CANADA
}

\author{
Edited by Rebecca Schiff and Helle Møller
}

Accounting for almost two-thirds of the country's land mass, northern Canada is a vast region, host to rich natural resources and a diverse cultural heritage shared across Indigenous and non-Indigenous residents. In this book, the authors analyse health and health care in northern Canada from a perspective that acknowledges the unique strengths, resilience, and innovation of northerners, while also addressing the challenges aggravated by contemporary manifestations of colonialism.

Old and new forms of colonial programs and policies continue to create health and health care disparities in the North. Written by individuals who live in and study the region, Health and Health Care in Northern Canada utilizes case studies, interviews, photographs, and more, to highlight the lived experiences of northerners and the primary health issues that they face. In order to maintain resilience, improve the positive outcomes of health determinants, and diminish negative stereotypes, we must ensure that northerners - and their cultures, values, strengths, and leadership - are at the centre of the ongoing work to achieve social justice and health equity.

REBECCA SCHIFF is a professor and chair in the Department of Health Sciences at Lakehead University.

HELLE MøLLER is an associate professor in the Department of Health Sciences at Lakehead University. 
This page intentionally left blank 


\section{Health and Health Care in Northern Canada}

EDITED BY

REBECCA SCHIFF AND HELLE MØLLER

UNIVERSITY OF TORONTO PRESS

Toronto Buffalo London 
(C) University of Toronto Press 2021

Toronto Buffalo London

utorontopress.com

Printed in the U.S.A.

ISBN 978-1-4875-0211-9 (cloth)

ISBN 978-1-4875-1461-7 (EPUB)

ISBN 978-1-4875-2179-0 (paper)

ISBN 978-1-4875-1460-0 (PDF)

\section{Library and Archives Canada Cataloguing in Publication}

Title: Health and health care in northern Canada / Rebecca Schiff and Helle Møller.

Names: Schiff, Rebecca (Professor of public health), author. | Møller, Helle, 1962- author.

Identifiers: Canadiana (print) 20210293535 | Canadiana (ebook) 20210293772 |

ISBN 9781487502119 (hardcover) | ISBN 9781487521790 (softcover) |

ISBN 9781487514617 (EPUB) | ISBN 9781487514600 (PDF)

Subjects: LCSH: Medical care - Canada, Northern. | LCSH: Medicine - Canada,

Northern. | LCSH: Indigenous peoples - Health and hygiene - Canada,

Northern. | LCSH: Canada, Northern - Social conditions.

Classification: LCC R463.N65 S35 2021 | DDC 362.109719 - dc23

This book has been published with the help of a grant from the Federation for the Humanities and Social Sciences, through the Awards to Scholarly Publications Program, using funds provided by the Social Sciences and Humanities Research Council of Canada.

University of Toronto Press acknowledges the financial assistance to its publishing program of the Canada Council for the Arts and the Ontario Arts Council, an agency of the Government of Ontario.

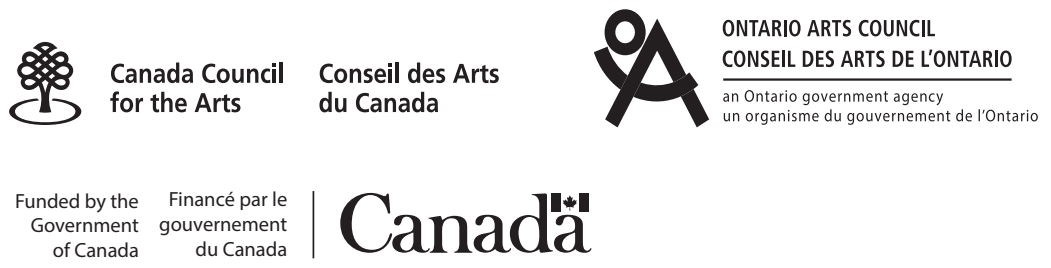

